\title{
Management of Africa's trans-boundary freshwater bodies: legal framework and challenges.
}

\author{
By John Osapiri*
}

\begin{abstract}
Research Presentation at the Online Leaders for Justice Workshop September and October 2021, organized by Konrad Adenauer Shiftung, Nairobi.
\end{abstract}

\section{A. ABSTRACT}

This paper discusses the Management of Africa's Trans boundary Fresh Water bodies focusing on challenges and the legal Framework guiding such natural resources. The author gives a detailed definition of Trans boundary fresh water bodies, gives an Overview of Africa Trans boundary Freshwater bodies and expounds on the Legal Framework regulating Africa Trans boundary water.

In discussing the Trans boundary legal framework for Africa, the author focuses on United Nations Convention on the Law of the Non-Navigational Uses of International Watercourses, the African Continental Treaties and the regional conventions legislating on shared Trans boundary Fresh water.

\section{B. The Concept of Trans-boundary Fresh Water Bodies}

Transboundary fresh water bodies have been defined to include the aquifers, and lake and river basins shared by two or more countries. ${ }^{1}$ These are simply waters that cross national boundaries. ${ }^{2}$ These water bodies support the lives and livelihoods of people that surround them. In this era of water stress and dilapidation of natural resources, how we manage these critical resources is vital for promoting peaceful cooperation and sustainable development. Millions of people around the world do not have enough water to sustain their livelihoods. Inadequate access to water is one of the main reasons for poverty and it affects

* The Author is the Chief Executive Officer of Uganda Christian Lawyers' Fraternity, and a Consultant on Regional Integration and cross border trade and investment. He is a Co-founder of the Center for Regional Integration in Uganda, a regional integration think tank. He holds a Masters of Laws with a Focus on Regional Integration from the University Dar es Salaam. He has extensively received training internationally at the University of Bayreuth Germany focusing on European Union Integration and the Germany Federal Systems of governance. His areas of interest are Regional integration law, Trade and Investment law, Commercial and Corporate practice and NGO Management.

1 UN Water, 'Transboundary Waters.' Accessed on https://www.unwater.org/water-facts/transboundar y-waters/ accessed on $2^{\text {nd }}$ September, 2021.

2 Jonathan Lautze \& Mark Giordano (2005), 'Trans-boundary Water Law in Africa: Development, Nature and Geography.' Natural Resources Journal Vol. 45, No. 4, P. 1 doi: https://www.jstor.org/sta ble/24889015. 
people's basic needs, health, food security and livelihoods. ${ }^{3} 145$ states have territory within Transboundary Lake or river basins, and 30 countries like entirely within them. ${ }^{4}$

There are approximately 276 transboundary river basins on the planet with a geographical area corresponding to almost half of the earth's surface and $60 \%$ of freshwater supplies. Almost three billion people in 145 countries live in this area. There are also approximately 600 hundreds aquifers shared by 2 or more countries. ${ }^{5}$ These physical realities, together with the need for sustainable development and the equitable and reasonable use of these transboundary resources, demand cooperation between people, groups, and states. ${ }^{6}$

The challenges of climate change, population growth, economic development and urbanization are straining the world's water resources and are exacerbating existing political tensions around Trans- boundary water management. ${ }^{7}$

\section{Synopsis of Africa Trans-boundary Freshwater Bodies.}

Africa is a land of Trans-boundary fresh waters, with the exception of Island States, every Africa country has a territory in at least one trans-boundary river basins. Trans-boundary basins cover $62 \%$ of Africa's total land area. ${ }^{8}$ Africa has about 63 trans-boundary river basins. ${ }^{9}$

Africa has about $9 \%$ of the world's fresh water resources and $16 \%$ of the world's population. There are about 17 rivers in the African continent. Among these rivers are the Congo, Nile, Zambezi, Niger and Lake Victoria, considered the world's second largest lake. ${ }^{10}$

For example; the Nile River Basin is one of the most critical transboundary water bodies in Africa, serving 11 countries including; Burundi, the Democratic Republic of Congo, Ethiopia, Kenya, Rwanda, South Sudan, Tanzania, and Uganda. This region is of

3 African Study Centre (2020), 'Water in Africa' https://www.ascleiden.nl/content/webdossiers/wate r-africa accessed on the $2^{\text {nd }}$ September, 2021.

4 UN Water (2005), 'Good Practices in transboundary Water Cooperation.' https://unece.org/fileadm in/DAM/env/water/publications/WAT_Good_practices/2015_PCCP_Flyer_Good_Practices_LIG HT_.pdf accessed on 2nd September.

5 UN Water (2015), 'Good Practices in trans-boundary Water Cooperation.' https://unece.org/filead $\mathrm{min} / \mathrm{DAM} / \mathrm{env} /$ water/publications/WAT_Good_practices/2015_PCCP_Flyer_Good_Practices_LI GHT_.pdf accessed on $2^{\text {nd }}$ September, 2021 .

6 Ibid.

7 Ibid.

8 Jonathan Lautze \& Mark Giordano (2005), 'Trans-boundary Water Law in Africa: Development, Nature and Geography.' Natural Resources Journal Vol. 45, No. 4, P. 1 doi: https://www.jstor.org/s table/24889015 accessed on 4th September, 2021.

9 Limpopo River Awareness Kit, 'Introduction to trans-boundary Water Management.' Available at http://www.limpopo.riverawarenesskit.org/LIMPOPORAK_COM/EN/GOVERNANCE/TRANS BOUNDARY_WATER_MANAGEMENT/INTRODUCTION.HTM accessed on 4th September, 2021.

10 African Study Centre (2020), 'Water in Africa' https://www.ascleiden.nl/content/webdossiers/wate r-africa accessed on the $2^{\text {nd }}$ September, 2021. 
special interest for two reasons: The first is the high degree of water resource interdependence between these countries, and the second is the historically high rate of armed conflict among them, within and across borders. Indeed, some observers have hypothesized that a causal relationship may exist between water resource interdependence and conflict. ${ }^{11}$

In the Southern African Development Community (SADC) region, there are over 15 trans-boundary rivers. SADC is an Economic Regional Community bringing together 12 countries in Southern Africa. South Africa, which is the most diversified economy in the SADC, shares six international watercourse systems with its neighboring States. The four most important basins are the Limpopo, Incomati, Maputo and Orange which are shared with Botswana, Lesotho, Mozambique, Namibia, Swaziland and Zimbabwe. ${ }^{12}$

The cross border shared water resources in West Africa include River Niger, Volta, the Gambia River, River Senegal, River Chari, Guir-Saoura, Mejerdah and Juba Shebelle.

The Africa Water Vision 2025 that aims to counter Africa's water problems has estimated that because of the growing water scarcity in Africa, 25 African countries will be water stressed by 2025 compared to 13 in $1995 .^{13}$

\section{The Legal Framework Regulating Africa Trans-boundary Water}

Since 1948, history shows only 37 incidents of acute conflict over water, while during the same period, approximately 295 international water agreements were negotiated and signed world over 14

According to the United Nations in 2020, only 24 countries reported that all their transboundary basins are covered by cooperation arrangements. ${ }^{15}$ This normative frameworks can organize relationships between countries to enable sustainable use of water resources.

This section comprises of an analysis of the Inter-continental, African Continental and regional framework regulating the management of trans-boundary fresh waters bodies in Africa.

11 AIDDATA (2013), 'Transboundary water Bodies and Conflict in Africa. https://www.aiddata.org/b $\log$ /transboundary-water-bodies-and-conflict-in-africa accessed on the 3rd September, 2021.

12 Limpopo River Awareness Kit, 'Introduction to trans-boundary Water Management.' Available at http://www.limpopo.riverawarenesskit.org/LIMPOPORAK_COM/EN/GOVERNANCE/TRANS BOUNDARY_WATER_MANAGEMENT/INTRODUCTION.HTM accessed on 4th September, 2021.

13 Economic Commission for Africa, 'Africa Water Vision, 2025: For equitable and Sustainable Use of Water for socioeconomic development.' https://www.afdb.org/fileadmin/uploads/afdb/Documen ts/Generic-Documents/african $\% 20$ water $\% 20$ vision $\% 202025 \% 20$ to $\% 20 \mathrm{be} \% 20$ sent $\% 20$ to $\% 20$ wwf 5.pdf accessed on $3^{\text {rd }}$ September, 2021.

14 UN Water (2005), 'Good Practices in transboundary Water Cooperation.' https://unece.org/fileadm in/DAM/env/water/publications/WAT_Good_practices/2015_PCCP_Flyer_Good_Practices_LIG HT_.pdf accessed on 2nd September.

15 Ibid. 


\section{International Legal Instruments on Freshwater Bodies.}

At the international level, the following treaties have been passed to regulate dealings with Trans-boundary Freshwater Bodies.

United Nations Convention on Trans Boundary Fresh Waters

The UN Convention on the Law of the Non-Navigational Uses of International Watercourses (UN Convention) of 1997 provides a framework and principles to guide basin level agreements.

This UN Watercourses Convention is intended to be a framework instrument of global applicability. As such, it complements the existing regional and water course specific legal architecture in three important situations: where no treaty regime exists between co-riparian states; where not all co-riparians are parties to an existing agreement; or where a watercourse is the subject of an existing agreement but that agreement only partially covers matters addressed by the UN Watercourses Convention. ${ }^{16}$

Even prior to its entry into force the Convention has played an important role, by informing the negotiation, adoption and interpretation of watercourse agreements at the regional or basin level, and informing the decisions of international courts.

Two African instruments, the Revised Protocol on Shared Watercourses in the Southern African Development Community (SADC) and the Nile River Basin Cooperative Framework Agreement, closely follow the UN Watercourses Convention.

As to international decisions, a mere four months after the Convention's adoption it was referred to by the International Court of Justice in support of the Court's judgment in the Gabcikovo-Nagymaros Project case. The Convention's basic principles are generally regarded as reflecting customary international law.

However, while the UN Watercourses Convention was adopted in 1997, the process for entry into force has been slow. Numerous factors must be in place for the Convention to realise its full potential. Amongst those factors, ensuring that the Convention is adopted and ultimately implemented will be contingent on the text of this legal instrument being accessible to a range of legal and non-legal experts involved in water issues. ${ }^{17}$

\section{African Regional Treaties on Trans Boundary Water.}

The African Union passed a treaty that is the 'African Convention on the Conservation of Nature and Natural Resources.' The objective of this Treaty is to enhance environmen-

16 United Nations, ' UN Water Courses Convention: User Guide.' https://www.iucn.org/sites/dev/file s/un_watercourses_convention_-_users_guide.pdf accessed on 20th November, 2021.

17 United Nations, ‘ UN Water Courses Convention: User Guide.' https:/www.iucn.org/sites/dev/file s/un_watercourses_convention_-_users_guide.pdf accessed on 20th November, 2021. 
tal protection, foster conservation and sustainable use of natural resources and harmonize policies in the field of ecology. ${ }^{18}$

This convention is considered the most forward looking regional agreement of the time, it influenced significantly the development of environmental law in Africa. Two and a half decades of intense developments in international environmental law made it necessary to revise this treaty, update its provisions and enlarge its scope. This was undertaken under the auspices of the African Union (previously OAU), and the revision was adopted by its Heads of State and Government in July 2003 in Maputo. ${ }^{19}$

The Convention proposes an Integrated Water Resources Management System (IWRM) aimed at promoting coordinated development and management of water resources. ${ }^{20}$ IWRM emphasizes the maximization of economic and social welfare in an equitable manner without compromising the sustainability of vital eco systems and the environment.

The Convention is further explicitly provides that where the water resource are trans boundary and shared by two or more States. Then the parties sharing such a water resource shall act in consultant or where the need arises set up an Inter State Commission. Such Commission will serve the purpose of promoting the rational, equitable and collective usage of such a resource. The Commissions are also charged with the resolution of disputes arising from the usage of such resources. The Commissions are to also to promote cooperative development, management and conservation of shared water resources. ${ }^{21}$

The Treaty also elaborately authorizes State Parties to the Treaty to undertake to cooperate in rational water husbandry. ${ }^{22}$ The Treaty further spells out that environmental procedural rights, where it emphasizes that the State Parties to the Treaty should ensure timely and appropriate dissemination of information regarding environmental information, enable access of the public to environmental information and ensure the participation of the public in decision making especially in environmental impact assessment. ${ }^{23}$

The African Commission on Human and People's Rights has issued Guidelines on the right to water in Africa. ${ }^{24}$ However these guidelines are not binding on State Parties to the African Union. The objective of the Guidelines on the Right to Water in Africa is to inform and support the work of States, while implementing the right to water, and in developing their periodic reports to the African Commission. The Guidelines elaborately provide guidance on International Cooperation on matters of water. Specifically it is provided that

18 Article 2, African Convention on the Conservation of Nature and Natural Resources, adopted in 1968 in Algiers1.

19 IUCN, 'An introduction to the African Convention on the conservation of nature and natural resources.' Doi: https://www.iucn.org/content/introduction-african-convention-conservation-nature -and-natural-resources-0.

20 African Convention on the Conservation of Nature and Natural Resources, Article 7 (2) b.

21 African Convention on the Conservation of Nature and Natural Resources, Article 7 (3).

22 Ibid, Article 7 (4).

23 Ibid, Article 16 (a-c).

24 African Commission on Human and People's Rights, 'Guidelines on the right to water in Africa. 
in order to guarantee the realization of the right to water across the African continent, States sharing one or more watercourses shall ensure that the allocation and use of water amongst riparian states are guided by the principles of reasonable and equitable utilization; no harm and cooperation, recognized as principles of customary international law for trans boundary fresh water resources. ${ }^{25}$

Africa Water Vision 2025 was adopted by the African Union and the Economic Commission for Africa, and calls for 'an Africa where there is an equitable and sustainable use and management of water resources for poverty alleviation, socioeconomic development, regional development and the environment' 26

\section{African Cross Boarder Framework Trans Boundary Fresh Water Framework.}

1. The Protocol for Sustainable Development of Lake Victoria Basin:

This has been wholly adopted by the Partner states of the EAC. The parties to the agreement are countries around the Lake Victoria basin. These countries have agreed to cooperate in sustainable management and development of basin in the areas of water resources, fisheries, wetlands, agriculture and land use as listed in Article 3 of the Protocol.

Indeed article 5 of the protocol concerns equitable and reasonable utilization of water resources.

Article 6 concerns protection and conservation of wild endangered fauna and flora, wetlands and fisheries resources. Article 12 requires states to develop Environmental Impact Assessments. Article 14 requires states to adopt legislation on environmental audits and notify each state member of activities that may have Trans boundary effects.

Article 16 requires states to take pre cautionary measures to avoid ecological damage to neighboring states. Article 17 introduces the polluter pays principle; Article 19 concerns prevention of pollution at the source.

Finally and most importantly is that this Protocol established the Lake Victoria Basin Commission to oversee the implementation and supervision of the protocol.

\section{The Lake Victoria Basin Commission Bill, 2019.}

The East African Legislative Assembly (EALA) is considering the Lake Victoria Basin Commission Bill (2019) with the aim of enacting the Lake Victoria Basin Commission Act which will be an act of the East African Community. The object of the Bill is to provide for the Lake Victoria Basin Commission as an institution of the Community and is premised on Chapter Nineteen of the Treaty for the Establishment of the East African

25 African Commission on Human and Peoples' Rights ('the African Commission') 'Guidelines on the Right to Water.' in Africa Part 6, Article 29.

26 Economic Commission for Africa, African Union, African Development Bank (undated): Africa Water Vision for 2025: Equitable and Sustainable Use of Water for Socioeconomic Development. 
Community, particularly Article 114, under which the Partner States agreed to cooperate in the management of their water and marine resources, and specifically, to establish a body for the management of Lake Victoria.

Inspite of the Bill being in the process of being enacted, the Lake Victoria Commission is operational. Lake Victoria Basin Commission (LVBC) is a specialized institution of the East African Community (EAC) located in the City of Kisumu, Republic of Kenya and within the Lake Victoria Basin (LVB). The Commission is mandated to coordinate sustainable development and management of the Lake Victoria Basin in the 5 EAC Partner States.

\section{Agreement on the Nile River Basin Cooperative Framework}

The text of the Cooperative Framework Agreement (CFA) outlines principles, rights and obligations for cooperative management and development of the Nile Basin water resources. Rather than quantifying 'equitable rights' or water use allocations, the Treaty intends to establish a framework to "promote integrated management, sustainable development, and harmonious utilization of the water resources of the Basin, as well as their conservation and protection for the benefit of present and future generations".

For this purpose, the Treaty envisages the establishment of a permanent institutional mechanism, the Nile River Basin Commission (NRBC). The Commission would serve to promote and facilitate the implementation of the CFA and to facilitate cooperation among the Nile Basin States in the conservation, management and development of the Nile River Basin and its waters. ${ }^{27}$

The Nile Basin Commission was therefore established to regulate the sustainable usage of the River Nile and govern relationships among the 11 countries that share this resource. The 11 countries include; Uganda, Burundi, the Democratic Republic of Congo, Ethiopia, Kenya, Rwanda, South Sudan, Tanzania and Egypt among others.

4. Protocol on the shared watercourses of the Southern African Development Community (SADC, 1998, 2003).

Since its creation in 1992, the SADC has been promoting regional integration, including water management. Several reference texts on water management have been promulgated, the SADC Water Protocol and its revised version in particular. On the basis of these protocols, agreements have been signed, ratified and have come into force for certain transboundary regional watercourses. They are behind the establishment of organizations in charge of managing river basins, i.e. River Basin Commissions. Subsequently, the SADC,

27 The Nile Basin Commission, 'Agreement on the Nile Basin Cooperative Framework.' http://www .nilebasin.org/index.php/about-us/the-nb-cooperative-framework see also www.nilebasin.org/inde x.php/nbi/cooperative-framework-agreement see also https://www.informea.org/en/treaties/agreem ent-nile-river-basin-cooperative-framework. 
which was restructured at the beginning of the second millennium, also elaborated policies and strategies concerning water resources in the region, and developed action plans. ${ }^{28}$

The SADC did not wait for the United Nations Convention on the Law of the Non-navigational Uses of International Watercourses to ratify its first protocol on water. In 1995 SADC ratified the Protocol on Shared Watercourses, being the first sector-based protocol developed by the SADC. This was revised on $7^{\text {th }}$ August, 2000.

The Protocol aims to foster closer cooperation among Member States for protection, management, and use of shared watercourses in the region. Member States agree to cooperate on projects and exchange information on shared watercourses, consulting with each other and collaborating on initiatives that balance development of watercourses with conservation of the environment. The Protocol also contains an institutional framework that sets out a Water Sector Organ, its committees and units, and its duties for joint protection and development of shared watercourses in Southern Africa.

\section{River Basin Commission in the SADC Region.}

This Protocol has facilitated the establishment of the River Basin Commissions in the SADC Region, which include

- Inkomati Tripartite Permanent Technical Commission; The Tripartite Permanent Technical Committee (TPTC) is a collaboration between South Africa, Mozambique and Swaziland. The cooperation on the joint management of the Inkomati Basin was initiated in 1992 with the signing of the Komati Accord between South Africa and Swaziland. Mozambique signed the Accord in 2002, making the TPTC one of the first RBO in Southern Africa. The mandate of the TPTC is to manage the water flow of the Inkomati River and Maputo River, specifically during times of flooding and drought. ${ }^{29}$

- International Commission of Congo-Oubanqui-Sanqha; The International Commission for the Congo-Oubangui-Sangha Basin (CICOS) was established in 1999. Member states of CICOS are Cameroon, Central African Republic, Democratic Republic of Congo and the Republic of Congo. The main objective of CICOS is to improve cooperation amongst the member states and eventually to promote Integrated Water Resources Management (IWRM). In recent years attention has been on large hydropower projects that use the large quantities of water from the Congo River. ${ }^{30}$

- Pangani Water Board; The Pangani River Basin covers an area of about 42,000 $\mathrm{km}^{2}$ shared between Kenya and Tanzania. The two countries established the Pangani Basin Water Board (PBWB) and the Pangani Basin Water Office (PBWO) in July

28 Agathe Maupin (2013), 'Regional Approach for Water Policies in Southern Africa.' https://hal.arc hives-ouvertes.fr/hal-00786053/document accessed on 10th September, 2021.

29 Limpopo River Awareness Kit. 'River Basin Organisations in the SADC.' http://www.limpopo.riv erawarenesskit.org/limpoporak_com/EN/GOVERNANCE/SADC/RIVER_BASIN_ORGANISAT IONS.HTM accessed on 16th September, 2021.

30 Ibid. 
1991 to jointly manage the water resources in the basin. The PBWO reports to the PBWB. The Board's task is to advise the basin water officer on all matters concerning: the apportionment of water supplies, the determination, diminution or modification of water rights, measures to be taken in case of drought, and on priorities to be given to different uses of water in the basin.

- Permanent Okavango River Basin Water Commission; The three Okavango Basin states Angola, Botswana and Namibia signed an agreement in 1994 that formed the Permanent Okavango River Basin Commission (OKACOM). The Agreement commits the member states to promote coordinated and environmentally sustainable regional water resources development, while addressing the legitimate social and economic needs of each of the riparian states. The three countries recognise the implications that developments upstream of the river can have on the resource downstream. Most of the river is currently undeveloped and is recognised as one of the few "near pristine" rivers in the world.

\section{E. WEST AFRICAN FRESH WATER REGIONAL FRAMEWORK.}

Covering less than 1/4 of the African continent, West Africa alone contains 25 of the 60 trans boundary river basins in Africa. With the exception of Cape Verde, each West African country shares at least one river with one of its neighbors.

The issue of trans-boundary water resource management is at the heart of the regional process of integrated water resource management (IWRM) in which all governments and river basin organizations of the region have been engaged since 1998, under Economic Commission of West African States (ECOWAS).

The ECOWAS regional process has led to adoption of Integrated Water Resource Management (IWRM) Regional Action Plan - December 2000, establishment of IWRM Permanent Framework for Coordination and Monitoring (PFCM) in West Africa - December 2001, and adoption of Water Resource Policy for West Africa - December 2008.

ECOWAS established the Water Resources Coordination Centre (WRCC). This Coordination Center has concluded consultations to establish a new governance body for the trans-boundary river basins of Comoe, Bia and Tano, in the West Africa Sub-Region.

Regional policy focuses on three strategic actions that is to promote investments in the water sector, reform water governance, promote cooperation and regional integration in water sector.

\section{F. CHALLENGES FACING AFRICA TRANS BOUNDARY FRESH WATER BODIES.}

- The absence of a regional legal framework for greater human rights-based cooperation in the management of trans-border waters, whereas Africa is the continent with the highest number of watershed. 
- Climate change is already impacting Africa's water resources through recurring droughts and floods. The increasing drying of some regions contributes to the arid land area that currently covers $60 \%$ of total land in Africa. Droughts are Africa's principle natural disasters with over $30 \%$ of the population exposed to this phenomenon. The intermittent floods that affect low lying areas have severe impacts on the livelihoods of the communities.

- The increasing water demands in the trans-boundary rivers and lakes due to increasing populations, settlement patterns and partly fueled by the recent so-called 'land grab' also poses risks for loss of biodiversity and diminished ecosystem services.

- The negative effects of overuse and pollution of water resources and other development activities threatening the rights of present and future generations, the realization of which depends on access to water.

- The right to water is not justiciable and not effectively protected by national courts within many jurisdictions in Africa;

- Regional Water Conflicts; the Mgingo Island conflict between Uganda and Kenya is a singular example of a cross border conflict on water.

- Non ratification and accent by State Parties to regional, intercontinental and Continental Treaties.

In conclusion, in order to guarantee the protection of Africa's shared fresh water, it's significant that countries ratify conventions intending to regulate the management of such water bodies. States should further take appropriate steps to protect such water sources from pollution, which threatens current and future existence of water bodies. 